AGNIESZKA BARTOSZEWICZ

Instytut Historyczny Uniwersytetu Warszawskiego

\title{
MOWA, GEST, PISMO. RELACJE MIĘDZY KULTURĄ ŻYWEGO SŁOWA A KULTURĄ PISMA W ŚWIETLE ZAPISEK Z KSIĄG SĄDOWYCH PÓŹNOŚREDNIOWIECZNYCH MIAST POLSKICH*
}

\begin{abstract}
Abstrakt: Każda zapiska zachowana w księgach miejskich stanowi efekt różnego rodzaju działań odbywających się w sferze słów i gestów, słuchanych, oglądanych i wreszcie przetworzonych przez pisarza w urzędowy zapis. Niniejszy artykuł stanowi próbę odpowiedzi na pytanie, jakie miejsce w tym świecie teatralnych gestów i utartych formuł zajmowało pismo.
\end{abstract}

Słowa kluczowe: miasto, XV w., słowo, gest, piśmienność.
Abstract: Any record registered in municipal books is a result of many actions in the sphere of words and gestures, listened to, seen, watched, and finally transformed by the scribe into an official registration. The present article attempts to answer the question about the place occupied by writing in that world of theatrical gestures and set phrases.

Keywords: town, city, the fifteenth century, word, gesture, literacy.

Prowadzone obecnie badania nad relacjami między kulturą żywego słowa a kulturą pisma w bardzo istotny sposób wzbogacają kwestionariusz badawczy historyków zajmujących się średniowieczną piśmiennością pragmatyczną, $\mathrm{w}$ tym spuścizną kancelaryjną ${ }^{1}$, także miejską. $\mathrm{W}$ tym

* Niniejszy artykuł stanowi wersję referatu wygłoszonego w październiku 2014 r. podczas zebrania Mediewistycznego i Nowożytnego Seminarium Doktorskiego Instytutu Historycznego UW. W tym miejscu chciałam serdecznie podziękować wszystkim dyskutantom za uwagi i pytania.

${ }^{1}$ Doskonale pokazuje to zestawienie literatury przedmiotu zawarte w bibliografii prac nad średniowieczną komunikacją: M. Mostert, A Bibliography of Works on Medieval Communication, Turnhout 2012, rozdz. 4: „Ritual”, 6: „Oral and Written Memory”, 13: „Uses of Writing in Government, Management and Trade”. Por. też artykuły znajdujące się $\mathrm{w}$ tomach Medieval Legal Process. Physical, Spoken and Written Performance in the 
ostatnim wypadku punktem wyjścia jest świadomość, że sporządzanie pisemnej dokumentacji było tylko jednym z elementów działań odbywających się przed sądem, swoistego theatrum, na który składały się gesty i słowa, nie zawsze notowane przez pisarza. Jak zauważył Marco Mostert: „Wzrost pisemnej dokumentacji nie oznacza jednak, że sprawdzone i budzące zaufanie procedury oralne nagle zniknęły, nawet jeśli profesjonaliści słowa pisanego - prawnicy, notariusze publiczni i świeccy urzędnicy wykształceni w szkołach prawniczych, mogli od tego momentu chcieć procedować tylko w zgodzie z pisemną dokumentacją"2. Sprawdzanie wiarygodności dokumentów przedstawionych jako dowody procesowe, sporządzanie zapisek czy dokumentów zawierających np. treść wyroku, głośne ich odczytanie było - zakładamy, że w XV w. coraz powszechniejszą - częścią składową przedstawienia ${ }^{3}$. Jedynym dostępnym dla nas śladem wydarzenia, które odbyło się przed sądem, jest zapisany wówczas tekst - dokument, protokół, a czasami zaledwie jednozdaniowa notka.

Większość dostępnych badaczom akt ławniczych i radzieckich składa się właśnie z pojedynczych, oderwanych wpisów dotyczących różnych spraw, co wynikało z trybu pracy pisarza, który notował tylko wybrane czynności urzędowe. Zapiski te mają na ogół lakoniczny, formularzowy charakter. Rzadko jesteśmy w stanie na ich podstawie zrekonstruować przebieg całego procesu, a zdarza się, że nawet nie wiemy, czego właściwie dotyczył spór. Przykładem może być zapiska z księgi ławniczej lubelskiej: „ławnicy wydali wyrok, że przezorny Andrzej ma zbyć zastaw Stanisława Białego" ". Tak wygląda jedyny pisemny dowód dokonanej

Middle Ages, red. M. Mostert, P.S. Barnwell, Turnhout 2011, oraz Oral History in the Middle Ages. The Spoken Word in Context, red. G. Jaritz, M. Richter, Krems 2001. Ostatnio na ten temat: D. Zupka, Ritual and Symbolic Communication in Medieval Hungary under the Árpád Dynasty (1000-1301), Leiden-Boston 2016, zwłaszcza podrozdział „An Outline of the Developments in the Later Middle Ages: Urban Rituals and Written Culture”, s. 189-194.

2 "The growth in written documentation did not mean, however, that the trusted ways of orality were abolished overnight, even if the specialist of the written word lawyers, notaries public and civil servants trained in the law schools - might henceforth wish to litigate on the evidence of written documents only", M. Mostert, Introduction, w: Medieval Legal Process, s. 3.

${ }^{3} \mathrm{~W}$ anglojęzycznej literaturze przedmiotu coraz częściej występuje właśnie takie określenie („,performance”) odbywających się publicznie działań. M. Mostert, Introduction, s. 3 nn.; G. Declercq, Between Legal Action and Performance. The "firmatio" of Charters in the Early Middle Ages, w: Medieval Legal Process, s. 55-73. Możemy się w tym miejscu także zastanowić, jaki wpływ na praktykę miejską średniowiecznej Polski miała wprowadzona w 1505 r. konstytucją Nihil Novi zasada promulgacji prawa, VC 1/1, s. 138-143.

${ }^{4}$ „Iurati decreverunt, quod providus Andreas debet vendere pignus Albi Stanislai”, Księgi wójtowsko-ławnicze miasta Lublina z XV wieku, wyd. G. Jawor, M. Kołacz-Chmiel, A. Sochacka, Lublin 2012 (dalej: Lublin), nr 37 (1458 r.). 
czynności prawnej. Za pomocą pojedynczego formularzowego zdania pisarz podsumował całą procedurę i cały rytuał prawny. Dodajmy przy tym, że odbyło się ono najprawdopodobniej - w tym wypadku - w języku polskim, podczas gdy zapiskę sporządzono po łacinie.

Warto zatem się zastanowić, w jaki sposób powstawały tego rodzaju notki oraz jak na ich sporządzanie wpłynęły ustne procedury odbywające się w języku rodzimym ${ }^{5}$, ponieważ analiza zawartości treściowej, struktury i języka zapisek pozwoli nam lepiej zrozumieć zależności występujące między twórcami a użytkownikami tych tekstów, mówiącymi, piszącymi, czytającymi, słuchającymi ${ }^{6}$. Przystępując do analizy zapisek zachowanych $\mathrm{w}$ księgach miejskich powinniśmy się zastanowić, jakie miejsce w tym świecie teatralnych gestów i utartych formuł zajmowało pismo, dokumenty i księgi ${ }^{7}$ oraz sporządzający zapiski pisarze.

\section{Gesty i ich znaczenie coram iudicio w świetle tekstów normatywnych}

Czynności prawne nie tylko były wykonywane, wszyscy zainteresowani musieli widzieć, że one były wykonywane ${ }^{8}$. Zagadnienie gestów prawnych przedstawionych w iluminowanych egzemplarzach Zwierciadła saskiego było już przedmiotem badań historyków9 ${ }^{9}$ Jest oczywiście

${ }^{5}$ Bartłomiej Groicki podkreślał, że działania sądu powinny odbywać się w języku zrozumiałym dla wszystkich uczestników procesu. Może to sugerować, że sądy nie zawsze przestrzegały tej zasady. Biorąc jednak pod uwagę, że Groicki opisywał praktykę krakowską, możemy przypuszczać, że problem dotyczył kwestii użycia języka polskiego bądź niemieckiego, a więc relacji między dwoma językami rodzimymi. B. Groicki, Porzadek sądów i spraw miejskich prawa majdeburskiego w Koronie Polskiej, Warszawa 1953, s. 65; idem, Artykuły prawa majdeburskiego. Postępek sądów około karania na gardle. Ustawa płacej u sąów, Warszawa 1954, s. 196. Por. K.A. Marciniak, Proces sadowy jako theatrum w świetle dziet Bartłomieja Groickiego, CPH 68, 2016, 1, s. 149-178.

${ }^{6}$ A. Butcher, Textual Production and Vernacular Behaviour: Locating a Fifteenth-Century Administrative Book, w: Vernacularity in England and Wales, c. 1300-1550, red. E. Salter, H. Wicker, Turnhout 2011, s. 295-299.

7 W jednym z pouczeń sądu wyższego prawa niemieckiego czytamy „Przysiężnicy mają ortel najć i prawo wyrzec podług pisanego prawa, jako jest prawo”, Najstarsze staropolskie tłumaczenie Ortyli magdeburskich według rękopisu nr. 50 Biblioteki Zakładu Narodowego im. Ossolińskich, cz. 2, oprac. J. Reczek, W. Twardzik, Wrocław 1972 (dalej: Ortyle), s. 304.

${ }^{8}$ M. Mostert, Introduction, s. 8.

9 J.-C. Schmitt, Gest w średniowiecznej Europie, Warszawa 2006 (oryg. franc. 1990), s. 21; R. Schmidt-Wiegand, Gebärdensprache im mittelalterlichen Recht, „Frühmittelalterliche Studien” 16, 1982, s. 363-379; eadem, Recht und Gesetz im Spannungsfeld zwischen Schriftlichkeit und Mündlichkeit im Mittelalter, „Frühmittelalterliche Studien” 27, 1993, 
mało prawdopodobne, żeby ławnicy z polskich miast dysponowali aż tak bogato zdobionymi, drogimi kodeksami. Nie zmienia to jednak faktu, że różnego rodzaju teksty normatywne, od Zwierciadła saskiego i Weichbildu magdeburskiego poczynając, poprzez pouczenia redagowane w sądach wyższych prawa niemieckiego aż po kodyfikację krakowskiej wersji prawa magdeburskiego dokonaną przez Bartłomieja Groickiego, nie pozostawiają wątpliwości, jak ważną funkcję w procedurze prawnej pełniły słowa i gesty. Dowodzą także, że od urzędników wymagano znajomości rytuału ${ }^{10}$.

Szczególnie wyraźnym przykładem współistnienia gestu, słowa pisanego i mówionego było w świetle tych źródeł posiedzenie sądu ławniczego. Powinno ono zacząć się od gajenia - swoistego przedstawienia, podczas którego wójt i ławnicy niczym aktorzy - odpowiednio ubrani i wyposażeni w stosowne rekwizyty ${ }^{11}$ - mieli wygłaszać swoje kwestie ${ }^{12}$. Odpowiednie gesty i słowa (okrzyki) były przewidziane także w wypadku zwoływania sądu koniecznego ${ }^{13}$. Podobnie było podczas wszystkich etapów procedury sądowej, od złożenia pozwu ${ }^{14}$ po apelację ${ }^{15}$. Pozawerbalne czynności były nieodłącznie związane z tzw. gwarem, czyli deklaracją powoda, że zakończył procedurę składania pozwu. W tym wypadku, poza wypowiedzeniem określonych formuł wymagano wzniesienia kciuka owiniętego w rękaw bądź podania sędziemu ręki ${ }^{16}$. Specjalną

s. 147-166; K. von Amira, Die Handgebärden in den Bilderhandschriften des Sachsenspiegels, München 1905, s. 161-263. Zob. też http://www.sachsenspiegel-online.de/export/ssp/ Erschliessung/bilderhandschriften.html (dostęp 9 VII 2014).

${ }_{10}$ B. Groicki, Artykuły; idem, Porządek. Więcej na ten temat: K.A. Marciniak, op. cit.

${ }^{11}$ R. Schmidt-Wiegand, Gebärdensprache, s. 372; M. Mostert, Introduction, s. 7. Odpowiednio uroczysty ubiór był wymagany podczas posiedzeń sądów wielkich. Por. A. Adamska, „Czy Pan wie, kto ja jestem?” Kilka uwag o mechanizmach percepcji wzrokowej i skuteczności kodów westymentarnych w późnośredniowiecznej Europie, w: Habitus facit hominem. Społeczne funkcje ubioru w średniowieczu i w epoce nowożytnej, red. E. Wółkiewicz, M. Saczyńska, M.R. Pauk, Warszawa 2016, s. 19-34. Autorce bardzo dziękuję za możliwość zapoznania się z maszynopisem tego tekstu.

12 Ortyle, s. 291-293; P. Szczerbic, Ius municipale to jest prawo miejskie majdeburskie nowo z łacińskiego i z niemieckiego na polski język z pilnościa i wiernie przełożone, wyd. G.M. Kowalski, Kraków 2011, passim.

13 R. Schmidt-Wiegand, Gebärdensprache, s. 368; B. Groicki, Porządek, s. 80. Por. też. G. Myśliwski, Rola dźwięku w społecznościach tradycyjnych, w: Aetas media, aetas moderna. Studia ofiarowane profesorowi Henrykowi Samsonowiczowi w siedemdziesiąta rocznice urodzin, red. H. Manikowska, A. Bartoszewicz, W. Fałkowski, Warszawa 2000, s. 685-688.

${ }^{14}$ B. Groicki, Porządek, s. 96-99; R. Schmidt-Wiegand, Gebärdensprache, s. 366-369; K. von Amira, op. cit., s. 171-172.

15 B. Groicki, Porzadek, s. 155-157.

16 Ibidem, s. 127-128. 
oprawę i szczególne znaczenie wszędzie i zawsze miał ceremoniał składania przysięgi ${ }^{17}$.

W tym ostatnim wypadku znaczenie gestu podkreślają zgodnie wszystkie przekazy źródłowe ${ }^{18}$. Wydaje się on być wręcz ważniejszy od słowa. W jednym z ortyli magdeburskich czytamy, że dowodzący swych praw do spadku po zmarłym „to ma ukazać na krzyżu sam swą ręką"19. W innym: „Gdyż ta niewiasta nie może mieć sądowego świadecstwa, co jej dano za wiano, tedy dzieci, słowie jej pasirbowie, bliszy są swą ręką przysiąc <...>, a nie chcą<li> oni przysiąc, tedy ona sama swą ręką przysiąc może, iż jej tako wiele wianowano, jako ona mieni"20. Podobny charakter mają też pouczenia sądu wyższego prawa magdeburskiego na zamku krakowskim, który notabene zalecał składanie przysięgi „tacto Sacramento", co wymagało szczególnej oprawy ceremonialnej ${ }^{21}$.

\section{Kultura prawna w późnośredniowiecznych polskich miastach}

Nie sposób jednak nie zadać pytania, czy procedurom odbywającym się przed sądami polskich miast, większych i mniejszych, rzeczywiście towarzyszyły rytuały przewidziane w aktach normatywnych. Jeśli tak było (nawet w ograniczonym stopniu), to wypada zapytać, jaką rolę pełniło podczas tych procedur słowo pisane. Odpowiedź na te pytania łączy się z kwestią kultury prawnej mieszczan ${ }^{22}$, ocenianej na ogół bardzo sceptycznie:

17 P. Szczerbic, op. cit., s. 241 nn.; R. Schmidt-Wiegand, Gebärdensprache, s. 376-378. Ostatnio na ten temat: G.M. Kowalski, Zwyczaj i prawo zwyczajowe w doktrynie prawa i praktyce sądów miejskich karnych w Polsce (XVI-XVIII w.), Kraków 2013, s. 135-140; M. Duda, S. Jóźwiak, Ze świata średniowiecznej symboliki. Gest i forma przysięgi w chrześcijańskiej Europie (X-XV w.), Kraków 2014 (zwłaszcza s. 173-192: „Przysięga sądowa”); M. Mikołajczyk, Proces kryminalny w miastach Małopolski XVI-XVIII wieku, Katowice 2013 (s. 371-394, rozdz. 10 „Przysięga dowodowa”, tu także wcześniejsza literatura przedmiotu).

18 Por. J.M. Bak, Non-Verbal Acts in Legal Transaction in Medieval Hungary and Its Environs, w: Medieval Legal Process, s. 236-238; Y. Zazuliak, ,Super tali re dubium periculosum est iuramentum". Oath-Taking and Dispute Procedures in Fifteenth-Century Galicia, w: ibidem, s. 247-265.

19 Ortyle, s. 262.

20 Ortyle, s. 287, podobnie s. 261, 327, 366.

${ }^{21}$ Decreta iuris supremi Magdeburgensis castri Cracoviensis. Rechtssprüche des Oberhofs des deutschen Rechts auf der Burg zu Krakau, t. 1: 1456-1481, wyd. L. Łysiak, K. Nehlsen von Stryk, Frankfurt am Main 1995, nr 87 (1457 r.), 156 (1458 r.) i passim; t. 2: 1481-1511, wyd. iidem, Frankfurt am Main 1997, nr 155 (1484 r.), 185 (1485 r.) i passim; M. Duda, S. Jóźwiak, op. cit., s. 80-83.

22 Osobnym problemem jest dyskusja tocząca się wokół definicji pojęcia „kultura prawna” („Rechtskultur”, „legal culture”). Najczęściej jednak pod tym terminem kryje 
Wielość i zakres spraw powodowały, że do końca XV w. nie było stałych, jednakowych form procesu w poszczególnych miastach [--] zwyczaj sądowy określony w prawie magdeburskim nie zawsze był możliwy do zastosowania w warunkach polskich. Powodowało to: rozbieżność między prawniczą terminologią a stanem faktycznym, widoczną m.in. przez pryzmat nieprecyzyjnych określeń stanowych; brak wyraźnych rozgraniczeń kompetencyjnych sądów, różnorodną formę procedowania i rady, i ławy ${ }^{23}$.

W wypadku wielu małych miast ta ocena jest z pewnością słuszna. Potwierdzają ją orzeczenia sądu wyższego prawa niemieckiego na zamku krakowskim, który niejednokrotnie miewał zastrzeżenia do kwalifikacji urzędników sądów niższych, wytykając im błędy czy niestaranność w formułowaniu zapytań ${ }^{24}$.

Nie możemy jednak całkowicie lekceważyć wiedzy na temat procedur prawnych posiadanej przez miejskich urzędników. Spora grupa mieszczan była zaangażowana w prace sądów wyższych prawa niemieckiego, których kolegia sędziowskie tworzyli miejscowi rajcy, np. w Bieczu, Kościanie czy Śremie ${ }^{25}$. Trzeba też zauważyć, że z porad prawnych sądów wyższych, które informowały m.in. o tym, jak procedury sądowe powinny wyglądać, korzystano dosyć powszechnie, czego dowodem jest 2736 ortyli wpisanych w latach 1456-1511 do akt sądu najwyższego prawa niemieckiego na zamku krakowskim ${ }^{26}$.

Można chyba zaryzykować stwierdzenie, że im wiedza i kultura prawna władz miejskich była większa, tym staranniej przestrzegano przepisanych prawem rytuałów. Możemy zaobserwować pewien paradoks: znajomość

się obowiązujący w danej społeczności zespół związanych z prawem wartości, norm, instytucji oraz sposobów zachowania i postępowania. Por. H. Rudolph, Rechtskultur in der Frühen Neuzeit. Perspektiven und Erkenntnispotentiale eines modischen Begriffs, „Historische Zeitschrift" 278, 2004, s. 347-374.

${ }^{23}$ H. Samsonowicz, Kultura prawnicza miast polskich $w$ średniowieczu, w: Mente et litteris. O kulturze i społeczeństwie wieków średnich, red. H. Chłopocka et al., Poznań 1984, s. 320.

${ }^{24}$ L. Łysiak, Raz jeszcze o założeniu sądu wyższego prawa niemieckiego na zamku krakowskim, „Studia z Dziejów Państwa i Prawa Polskiego” 4, 1999, s. 107.

${ }^{25}$ L. Łysiak, Sąd wyższy prawa niemieckiego w Bieczu, CPH 33, 1981, 1, s. 8; W. Maisel, Są wyższy prawa magdeburskiego w Poznaniu (do końca XVI wieku), „Studia i Materiały do Dziejów Wielkopolski i Pomorza" 2, 1956, 2, s. 29-41; Materyały do historyi miasta Biecza (1361-1632), oprac. F. Bujak, Kraków 1914, nr 10 (Jan mieszczanin biecki i wójt sądu wyższego, 1383 r.). W Wielkopolsce ortyle wydawały sądy wyższe działające w przynajmniej siedmiu miastach (Poznań, Kościan, Śrem, Gostyń, Inowrocław, Gniezno, Kalisz), Ortyle sądów wyższych miast wielkopolskich z XV i XVI wieku, oprac. W. Maisel, Wrocław 1959, s. XVI.

${ }^{26}$ Decreta iuris supremi Magdeburgensis castri Cracoviensis, passim. 
pisma, a precyzyjniej: dostęp urzędników - zapewne za pośrednictwem profesjonalisty pióra - do tekstów normatywnych powodował, że zgodne z wymogami prawa ustne wypowiedzi i gesty odgrywały coraz większą rolę w funkcjonowaniu miejskich urzędów. Interesującym przykładem może tu być działalność urzędów ławniczych. Wraz ze wzrostem kultury prawnej posiedzenie ławy nabierało cech długotrwałego spektaklu, w którym brali udział sędziowie, strony, świadkowie. Wiodącą rolę w tym przedstawieniu odgrywali ci, którzy wiedzieli, według jakich reguł powinno ono przebiegać: pisarz miejski, wójt i podwójci, zapewne też jakaś grupa ławników zaliczających się do grona miejskich litterati (czy raczej semi-litterati), czasami ktoś spośród klientów sądu. W tym ostatnim wypadku kluczowe wydają się być postacie rzeczników (zastępców sądowych) i opiekunów sądowych. W tym gronie znajdowali się często ludzie zawodowo lub półzawodowo zajmujący się reprezentowaniem stron w sądzie ${ }^{27}$, zorientowani w procedurach i potrafiący wypełnić swoje obowiązki zgodnie z wymogami prawa ${ }^{28}$.

\section{Zapisy w księdze ławniczej jako świadectwo ustnych procedur sądowych}

Wydaje się, że poziom pisarski księgi - między innymi - miał związek ze stopniem znajomości przepisów określających rytualne czynności towarzyszące działaniom sądu. Innymi słowy, księga ławnicza z wpisami starannie sporządzanymi przez pisarza miejskiego, informującymi o zebraniach sądów gajonych, odbywających się w przewidzianych przez prawo terminach, pozwala nam stwierdzić, że władze miejskie zatrudniały fachowca, który nie tylko miał kwalifikacje pisarskie, ale także mógł wystąpić w roli reżysera (może suflera) przedstawienia odgrywanego coram iudicio. W tych przypadkach możemy z całym przekonaniem uznać, że każda zapiska w księdze jest efektem odegranego przed sądem theatrum, a raczej - jej sporządzenie było elementem tego spektaklu. Równocześnie mamy możliwość przeanalizowania znajdujących się w tych zapiskach śladów poświadczających, że procedury przewidziane przez prawo istotnie miały miejsce.

27 Zapiski w księgach miejskich wszystkich chyba ośrodków dowodzą popularności instytucji zastępstwa procesowego, więcej na ten temat: A. Bartoszewicz, Piśmienność mieszczańska w późnośredniowiecznej Polsce, Warszawa 2012, s. 197 nn.

${ }^{28}$ O gestach, które powinni wykonywać zastępcy sądowi: K. von Amira, op. cit., s. $194 \mathrm{nn}$. 
Pierwszą przesłanką, choć może najmniej przekonywającą, jest powoływanie się na przepisy prawa magdeburskiego, chełmińskiego czy ogólniej prawa niemieckiego lub miejskiego ${ }^{29}$. Nie wiemy, czy we wszystkich miastach odbywało się uroczyste gajenie sądu, ale przynajmniej w niektórych wypadkach wydają się to poświadczać informacje zachowane w nagłówkach wpisów w księgach ławniczych czy zawarte $\mathrm{w}$ treści zapisek ${ }^{30}$. W ich świetle nie ulega też wątpliwości, że odbywały się również inne przewidziane przez prawo czynności. Przy pomocy odpowiedniego gestu gwarantowano, że treść oskarżenia nie zostanie zmieniona ${ }^{31}$. Przedstawiano środki dowodowe w postaci świadków, składających przysięgę na krzyż lub na Eucharystię ${ }^{32}$. Uroczyście odwoływano pozwy ${ }^{33}$ i odbywano procedurę czterokrotnego okazywania i przedstawiania do wykupu zastawu ${ }^{34}$. Wreszcie wiemy, że oświadczenia składane przez występujących przed sądem wygłaszano clara voce i wielokrotnie powtarzano ${ }^{35}$. Pewną przesłankę stanowią również zapiski o charakterze protokolarnym, zawierające cytaty z wypowiedzi stron. Przetłumaczone na łacinę brzmią one dosyć pompatycznie i zawsze zaczynają się - zgodnie z wymogami prawa - od słów „domine advocate"

${ }^{29}$ Np. Lublin, nr 369 (1467 r.), 1114 (1471 r.); Księga ławnicza miasta Nowej Warszawy, t. 1: 1416-1485, wyd. A. Wolff, Wrocław 1960 (dalej: Nowa Warszawa), nr 97 (1429 r.), 409 (1459 r.), 609 (1464 r.).

30 „[podwójci] proclamavit alias vyvolal gaye”, Księgi sądowe miasta Wąolnicy z lat 1476-1500, oprac. G. Jawor, A. Sochacka, red. R. Szczygieł, Lublin 1998, nr 14 (1488 r.).

${ }^{31}$ Ceremoniał czynienia gwaru (satisdatio), Lublin, nr 1030 (1471 r.), 1282 (1473 r.), 1439 (1474 r.), 1579 (1475 r.).

${ }^{32}$ Lublin, nr 27 (1465 r.), 1440 (1474 r.); Księga ławnicza miasta Płocka 1489-1517, oprac. D. Poppe, Warszawa 1995, nr 548 (1515 r.).

${ }^{33}$ Lublin, nr 66 (1469 r.).

34 M.in. Lublin, nr 116, 126, 129, 153, 161, 168 (1465 r.).

35 „Grzegorz Lis przepytywany przez wójta na okoliczność nazwania mieszczanina Mikołaja Filca złoczyńcą oświadczył, że nic złego o nim nie wie, a tylko wszystko dobre, co powtórzył cztery razy", Lublin, nr 989 (1471 r.). Z drugiej strony mamy zapiskę informującą o milczącym odstąpieniu od sprawy („recessit silenter a iudicio”, ibidem, nr 614, 1468 r.).

36 „Domine advocate. Ex quo Deo et iusticia dominus meus docuit testibus forum vendicionem...", Lublin, nr 175 (1465 r.); podobnie: ibidem, nr 449 (1467 r.); Księgi sądowe miasta Wąwolnicy, nr 52 (1486 r.), 146 (1494 r.). Bardzo interesującym źródłem są przekazy wernakularne m.in. mów wygłaszanych przed sądami. Por. K. Mrozowski, Spór „o spadek y o ymieye” a kultura prawna mieszkańców Starej Warszawy w połowie XVI wieku, KHKM 61, 2013, 2, s. 292-294 („Mowa sądowa pełnomocnika Andrzeja Wierczioszka"). 
Pismo a kultura żywego słowa w procedurach sądowych

Większość przekazów źródłowych na temat roli pisma w trakcie procesu sądowego pochodzi z ośrodków relatywnie dużych, liczących minimum 2-2,5 tys. mieszkańców (Lublin, Płock, Stara Warszawa). W wypadku mniejszych miast wątła baza źródłowa nie pozwala nam niejednokrotnie nawet określić, kiedy zaczęto tam prowadzić dokumentację pisaną, a tym bardziej badać relacji między żywym słowem a kulturą pisma. Wydaje się jednak, że pierwsza połowa XV w. była okresem przełomowym, zarówno w zakresie prowadzenia ksiąg sądowych, jak i przedstawiania środków dowodowych w postaci dokumentów czy powoływania się na dokonane wcześniej wpisy w księgach ${ }^{37}$.

Ceremoniał i wielokrotne powtarzanie formuł służyły zapamiętaniu przez obecnych istoty sprawy, aby $\mathrm{w}$ razie potrzeby byli $\mathrm{w}$ stanie zaświadczyć, że dana czynność odbyła się przed sądem ${ }^{38}$. Podobną rolę spełniały także różnego rodzaju działania związane zarówno ze sporządzaniem zapisów, jak i odczytywaniem zaprezentowanych dokumentów. Przede wszystkim jednak oznaczały one wzbogacenie toczącego się przed sądem spektaklu o nowe elementy. Jednym z nich było głośne odczytanie dokumentu przez, najczęściej, pisarza lub podwójciego, a w wypadku pozostałych osób „odsłuchanie” (zgodnie z treścią zapisek w księgach miejskich dokumentów się słucha ${ }^{39}$ ). Akt odczytania - wysłuchania nie był jednak jedynym składnikiem tej ceremonii. W niektórych wypadkach zainteresowane strony trzeba było wezwać za pośrednictwem miejskiego woźnego, by stawiły się w celu „wysłuchania czytanego pisma” (ad audiendum legi litteram ${ }^{40}$ ) bądź było to przedmiotem osobnych ustaleń ${ }^{41}$. Innym elementem spektaklu było uznanie wiarygodności dokumentu przedstawionego przez stronę ${ }^{42}$. W tym wypadku podstawowe znaczenie miała znowu sfera wizualna: obejrzenie pieczęci i jej akceptacja. Wpisy w księgach sądowych niejednokrotnie zawierają podkreślenie, że przed sądem przedstawiono dokument $\mathrm{z}$ właściwą pieczęcią - littera bene sigillata ${ }^{43}$.

37 Najdawniejsze zapiski z księgi miejskiej Pleszewa (1428-1444), wyd. T. Jurek, Poznań 2011, nr 4 (1428 r.); Nowa Warszawa, nr 220 (1447 r.).

${ }^{38}$ Lublin, nr 258 (1487 r.); Najdawniejsze zapiski z księgi miejskiej Pleszewa, nr 27 (1483 r.); Księga ławnicza miasta Płocka, nr 109, 110 (1499 r.).

39 „ius dicta privilegia exaudire debet”, Lublin, nr 1168 (1472 r.).

${ }^{40}$ Lublin, nr 1264, 1276 (1472 r.), 1284 (1473 r.).

${ }^{41}$ Lublin, nr 1371 (1473 r.).

${ }^{42}$ Lublin, nr 218 (1466 r.).

${ }^{43}$ Księgi sądowe miasta Wąwolnicy, nr 199 (1495 r.); Lublin, nr 1619 (1475 r.). 
Przywoływaniu świadectwa wpisów znajdujących się w księgach sądowych i zbiorach przepisów także, jak można przypuszczać, towarzyszyła stosowna oprawa ${ }^{44}$.

Warto zadać sobie pytanie, w jaki sposób dokonywano zapisów w księgach. Czy odbywało się to publicznie, w obecności zainteresowanych stron i świadków, a zapis był potem uroczyście odczytywany (odsłuchiwany)? Na to pytanie trudno jednoznacznie odpowiedzieć. „Nie wolno też zapominać, że w epoce, w której jedyny znany sposób pisania to ruch ręki (również mającej istotne znaczenie symboliczne) po pergaminie, pismo jest także gestem" ${ }^{45}$. Idąc tropem tej myśli Jean-Claude’a Schmitta, powinniśmy uznać, że sporządzanie wpisu stanowiło nieodłączny element spektaklu odgrywanego przed urzędem. Nie ulega wątpliwości, że czytając zapiski w rodzaju: „rajcy polecili wpisać ugodę do księgi miejskiej” ${ }^{46}$, „na pamiątkę tej rzeczy nakazujemy wpisać do księgi naszej sądowej” ${ }^{47}$ czy: „,rajcy zezwolili wpisać tę ugodę do akt miejskich" 48 możemy się domyślać, że polecenie dokonania zapisu zostało wygłoszone publicznie. Stanowiło odpowiedź na prośbę zgłoszoną przez zainteresowaną tym osobę $e^{49}$ i towarzyszyły mu stosowne gesty ${ }^{50}$, może także przyniesienie księgi, która przynajmniej w mniejszych miastach nie była stałym rekwizytem zebrania urzędników ${ }^{51}$. Można też chyba

${ }^{44}$ Lublin, nr 884, 845 (1469 r.), 943 (1470 r.).

${ }^{45}$ J.-C. Schmitt, op. cit., s. 13.

46 Najdawniejsze zapiski z księgi miejskiej Pleszewa, nr 2 (1429 r.). Podobnie Księgi sądowe miasta Wąwolnicy, nr 14 (1488 r.).

${ }^{47}$ AGAD, Księgi miejskie Warta, sygn. Warta 1 (dalej: Warta 1), s. 114 (1486 r.). Podobnie ibidem, s. 115 (1486 r.). W tym wypadku oba wpisy zostały dokonane ręką przygodną, należącą do osoby, która zastępowała stałego pisarza miejskiego.

${ }^{48}$ Księgi sądowe miasta Wąwolnicy, nr 16 (1481 r.). Podobnie: ibidem, nr 33 (1483 r.).

49 Ibidem, nr 17 (1482 r.), 23 (1483 r.?), 52, 54, 55 (1486 r.).

${ }^{50}$ K. von Amira, op. cit., s. 212 nn. („Befehlgestus”). Bezpośrednie informacje o wyartykułowaniu przez urzędników polecenia dokonania wpisu znajdujemy w zapiskach z ksiąg miejskich niezbyt często. Nie znaczy to jednak, że tego rodzaju polecenia, w odpowiednio wyeksponowanej formie, nie były wydawane częściej. Przywołane wyżej cytaty pochodzą z zapisek o dosyć standardowym charakterze, m.in. ugody między krewnymi wpisanej do księgi radzieckiej Pleszewa i transakcji kupna sprzedaży domu w Warcie. Analogiczne czynności prywatnoprawne wpisywano do ksiąg miejskich masowo, na ogół bez zaznaczania, kto nakazał sporządzenie zapiski. Umieszczenie informacji o tym było chyba inicjatywą pisarza, może nie do końca oswojonego z formularzem, a w każdym razie z jakichś powodów chcącego lakoniczny zapis na temat istoty transakcji uzupełnić o dodatkowe informacje. Zwróćmy przy tym uwagę na to, że tego rodzaju przekazy pochodzą najczęściej z mniejszych ośrodków (Wąwolnica, Warta, Pleszew), w których zatrudniano pisarzy nie zawsze dobrze obytych z praktyką pracy w kancelarii miejskiej.

51 Por. przyp. 57. 
przypuszczać, że przynajmniej w takich przypadkach pisarz sporządzał od razu zapis, choć nie zawsze od razu był on ostateczny i notowany na czysto w księdze.

Trzeba pamiętać, że w większości ksiąg ławniczych możemy natknąć się na puste miejsca, czasami opatrzone nagłówkiem, oznaczające, że pisarz zaplanował sporządzenie zapiski, ale z jakichś powodów zrezygnował z tej czynności. Zdarza się też, że w tekście zapisek pozostawione są wolne miejsca, a dane, takie jak np. imię czy przydomek którejś z osób występujących przed sądem, suma pieniędzy będąca przedmiotem sprawy czy dzień posiedzenia sądu, miały być uzupełnione później ${ }^{52}$. Może to sugerować, że głośne odczytanie zapiski (jej roboczej wersji?) podczas posiedzenia ławy nie zawsze ostatecznie kończyło sprawę, a pisarz mógł potem dokonać uzupełnień. Nie możemy też wykluczyć, że na życzenie stron można było dokonać jakichś zmian. W tym kontekście warto przyjrzeć się różnego rodzaju poprawkom, które zostały naniesione w tekście zapisek. Przykładem może być notka z księgi ławniczej Nowej Warszawy dotycząca sprzedaży domu przez mieszczanina Marcina, którego pisarz pierwotnie określił przydomkiem „Śmierdzimiech”. To określenie (przezwisko) zostało jednak wykreślone i zastąpione zdecydowanie mniej obraźliwym „Żywotek”53, jak można przypuszczać z inicjatywy najbardziej zainteresowanej osoby.

Tekst wpisów miał duże znaczenie, ponieważ były one później użytkowane, stanowiły m.in. podstawę do wydawania wyroków ${ }^{54}$ i stwierdzania ważności środków dowodowych ${ }^{55}$, a także powoływano się na nie podczas realizowania zawartych $\mathrm{w}$ nich postanowień ${ }^{56}$. $\mathrm{Z}$ tym także wiązały się różne ceremonie. Z 1444 r. pochodzi zapiska z księgi pleszewskiej, opisująca, jak wobec licznych świadków „obecni na sądzie gajonym polecili przynieść księgę i za zgodą stron ją otworzyli..." i wysłuchali interesującego ich zapisu ${ }^{57}$. Podobnie w lubelskiej księdze ławniczej zapisano, że szlachcic Piotr Koniński upoważnił mieszczanina Marcina Klozmana do wysłuchania orzeczenia zapisanego w księdze

${ }^{52}$ Np. Lublin, nr 908 (1470 r.); AGAD, Księgi miejskie Stara Warszawa, sygn. 527, k. 38 (1455 r.), 39v. (1456 r.); sygn. 529, k. 49, 64v. (1514 r.).

53 Nowa Warszawa, nr 459 (1458 r.).

54 „Ius decrevit ex sententia librorum”, Lublin, nr 1209 (1472 r.); podobnie: Lublin, nr 1372 (1473 r.)

55 „Ius decrevit, quia testimonium antiquum contra Nicolaum Neco [--] extunc libri decreverunt, quod illud testimonium iam sibi invanum tradit", Lublin, nr 1206 (1472 r.).

${ }^{56}$ Lublin, nr 1521 (1474 r.).

57 Najdawniejsze zapiski z księgi miejskiej Pleszewa, nr 54. 
i pobrania należnych Piotrowi pieniędzy zgodnie z tym, ,jak szerzej w aktach się zobowiązali" ${ }^{58}$. Wynika z tego, że realizację wcześniejszych postanowień poprzedzało odczytanie stosownego wpisu w księdze i publiczne sprawdzenie, czy wszystko zostało wykonane „zgodnie z wcześniejszym wpisem" 59 .

Na ogół uznaje się, że dokonanie wpisu w księdze było aktem woli jednej ze stron, tej, która chciała mieć pisemny dowód dokonanej czynności prawnej przed sądem czy przez sąd. Zachowały się jednak wzmianki wskazujące, że urzędnicy miejscy musieli wyrazić zgodę na sporządzenie zapiski w księdze ${ }^{60}$. Oczywiście mogło chodzić jedynie o pieniądze zapłacone (bądź nie) za pracę pisarza, ale wydaje się, że pilnowano, by do księgi trafiały notki dotyczące spraw o odpowiedniej randze. $Z$ drugiej strony uważano, że ważne sprawy powinny zostać zapisane. Interesująca wydaje się być w tym kontekście zapiska zachowana w księdze ławniczej lubelskiej, informująca o zwróceniu się przez ławę do sądu wyższego o pouczenie, czy prawo nakazuje wpisać do księgi sądu ławniczego pozew mieszczki Elżbiety Gębaliny oraz jej zeznanie ${ }^{61}$. Zdarzało się także, że to urząd z własnej inicjatywy nakazywał sporządzenie zapisu, np. w $1471 \mathrm{r}$. lubelska ława zadecydowała o wpisie dotyczącym okazania określonej sumy pieniędzy przez jednego z mieszczan ${ }^{62}$.

Mając na uwadze nadzór władz miejskich nad częstotliwością i treścią wpisów wprowadzanych do ksiąg, nie możemy oczywiście zapominać, że zapis w księdze czyniono „dla lepszego świadectwa"63. Wydaje się jednak, że musimy tutaj wyraźnie odróżnić sprawy, które musiały być uwierzytelnione na piśmie, od tych niewymagających takiej formy potwierdzenia. W tym wypadku wiele zależało od praktyki i ustawodawstwa danego ośrodka ${ }^{64}$, a banalne będzie stwierdzenie, że ten proces był najbardziej zawansowany w dużych miastach.

Osobną kwestią jest pytanie, czy anulowanie wpisów znajdujących się w księgach sądowych miało jakąś ceremonialną oprawę. Zapiski

58 „uti lacius se ad acta inscripserunt”; podobnie: „ad audiendum sentenciam ex libris legum”, Lublin, nr 1147 (1472 r.).

59 „iuxta priorem inscriptionem”, Lublin, nr 1167 (1472 r.).

${ }^{60}$ Np. Księgi sądowe miasta Wąwolnicy, nr 16 (1481 r.). Por. też przyp. 46-49.

61 Lublin, nr 155 (1465 r.).

${ }^{62}$ Np. Lublin, nr 1075; por. też Najdawniejsze zapiski z księgi miejskiej Pleszewa, nr 2 (1429 r.).

63 „propter magis testimonium”, Nowa Warszawa, nr 975 (1483 r.).

${ }^{64} \mathrm{~Np}$. w Krakowie już w drugiej połowie XIV w. istniał ustawowy obowiązek uwierzytelniania na piśmie zapisów wiana. Najstarszy zbiór przywilejów i wilkierzy miasta Krakowa, cz. 2, wyd. S. Estreicher, Kraków 1936, nr 15 (1378, 1397 r.); J. Wysmułek, Testamenty mieszczan krakowskich (XIV-XV wiek), Warszawa 2015, s. 84. 
informujące o takiej czynności ${ }^{65}$, a przede wszystkim liczne przekreślone noty w księgach ${ }^{66}$ świadczą, że było to zjawisko powszechne. Na pewno ogłaszano wobec świadków akt anulowania testamentów czy darowizn ${ }^{67}$, podobnie postępowano chyba także w innych przypadkach, choć pisarze raczej sporadycznie zaznaczali, że wykreślenie zapiski odbyło się w obecności czy za aprobatą miejskich urzędników ${ }^{68}$. W niektórych wypadkach skasowanie zapisu było niewątpliwie częścią werdyktu wydanego przez sąd, a zatem było ogłaszane publicznie. Wpisy zawierające tekst wyroków nakazujących wykreślenie wszystkich wcześniejszych not dotyczących danej sprawy są jednak raczej rzadkością ${ }^{69}$.

\section{Przekazanie praw do nieruchomości}

Mechanizm podejmowania decyzji o sporządzeniu zapisu dokonanej czynności prawnej możemy bliżej poznać i zrozumieć, analizując wpisy dotyczące przekazania praw własności do nieruchomości. Działanie tego rodzaju, sprzedaż bądź darowizna, we wszystkich systemach prawnych miało swoją specyficzną oprawę ${ }^{70}$. W jaki sposób zawarcie takiej umowy przebiegało $\mathrm{w}$ interesujących nas późnośredniowiecznych miastach polskich, możemy się tylko domyślać. Zgodnie z przepisami prawa magdeburskiego, w celu potwierdzenia dokonanej czynności prawnej sędzia powinien nałożyć czapkę, wziętą od sprzedawcy, na głowę kupującego. Poza Krakowem - jak stwierdza Bartłomiej Groicki - obowiązywał natomiast zwyczaj wręczenia kupcowi w dłoń zielonej rózgi ${ }^{71}$. Czy rzeczywiście tak wyglądała praktyka, trudno powiedzieć. Przede wszystkim musimy pamiętać, że transakcje kupna-sprzedaży odbywały się nie tylko przed

65 Lublin, nr 1330 (1473 r.); Księga ławnicza miasta Płocka, nr 137 (1501 r.), 219 (1505 r.).

${ }^{66}$ Często opatrzone zapiską informującą np. o spłacie długu, np. Księgi sądowe miasta Wawolnicy, nr 37 (1484 r., dopiski z 1495 r.), 53 (1486 r.); Księga ławnicza miasta Płocka, nr 174 (1503 r.), 197 (1504 r.), 223 (1505 r.) i passim.

${ }^{67}$ Księgi sądowe miasta Wąwolnicy, nr 104 (1490 r., unieważnienie wcześniejszych zapisów dotyczących podziału dóbr i przeprowadzenie nowego działu); AGAD, Księgi miejskie Stara Warszawa, sygn. 527, k. 210 (1467 r., skasowany testament).

68 „Et penes istam destruccionem sunt presentes providi domini consules”, Księgi sądowe miasta Wąwolnicy, nr 237 (1497 r.). Podobnie: Księga ławnicza miasta Płocka, nr 219 (1505 r.).

${ }^{69}$ „Mortificant omnes inscripciones”, Księgi sądowe miasta Wąwolnicy, nr 18 (1482 r.). Podobnie: Księga ławnicza miasta Płocka, nr 101 (1499 r.).

70 Por. J.M. Bak, op. cit., s. 236-238.

71 B. Groicki, Porzadek, s. 77-78. W Ius municipale Pawła Szczerbica jest tylko mowa o przekazaniu czapki, P. Szczerbic, op. cit., s. 105. 
sądem. Wręcz przeciwnie - znaczna część takich spraw była załatwiana w karczmach, gospodach cechowych ${ }^{72}$, prywatnych domach ${ }^{73}$, wreszcie $-\mathrm{w}$ miejscu, które było przedmiotem transakcji ${ }^{74}$. Księgi miejskie nie zawierają żadnych wzmianek na temat towarzyszących temu działań, werbalnych i pozawerbalnych, choć wyraźnie podkreślają, jak ważna była obecność świadków - litkupników, wśród których często byli urzędnicy, zresztą nie tylko miejscy ${ }^{75}$. Gdy taką transakcję urzędowo potwierdzano, przynajmniej w niektórych przypadkach ${ }^{76}$ odbywała się procedura opisana przez Groickiego, tak samo jak wtedy, gdy sprawę załatwiano od początku do końca przed sądem gajonym. W XV w. na wsi przekazanie praw własności do nieruchomości obejmowało ceremonię wręczania zielonej rózgi nabywcy. Informacje tego rodzaju powtarzają się we wpisach do niemal wszystkich wiejskich ksiąg sądowych ${ }^{77}$, świadcząc tym samym, jak ważnym rekwizytem przy tego rodzaju transakcjach była owa zielona gałąź. Natomiast w księgach miejskich rzadko jest o tym mowa. Zachowały się jednak wzmianki w księdze sądowej Wąwolnicy świadczące o tym, że przekazanie zielonej gałęzi rzeczywiście było istotnym elementem procedury przekazania praw do nieruchomości. Animatorem całego ceremoniału był podwójci, który odbierał rózgę od strony sprzedającej, czterokrotnie obwoływał sprawę i - gdy nie było sprzeciwu - wręczał gałąź drugiej stronie, a następnie zlecał dwóm ławnikom udanie się do rajców, by ci nakazali wpisanie transakcji do miejskiej księgi ${ }^{78}$.

Szczegółowe opisy tej procedury znajdujące się w księdze wąwolnickiej stanowią swego rodzaju wyjątek. Możemy jednak zakładać, że wiele innych zapisek informujących o sprzedaży nieruchomości po prostu pomija tego rodzaju czynności. Otwarte pozostaje pytanie, kto decydował o uwierzytelnieniu transakcji przed sądem w wypadku, gdy odbyła się

${ }^{72}$ Lublin, nr 155 (1465 r., potwierdzenie transakcji zawartej w siedzibie cechu prasołów).

${ }^{73}$ Ksiegga ławnicza miasta Płocka, nr 96 (1498 r.), 113 (1499 r.).

74 Lublin, nr 1570 (1474 r.).

75 Lublin, nr 751 (1461 r. - wśród litkupników podwójci Maciek Fiolek i pisarz Eligiusz); nr 827 (1469 r. - burmistrz, rajcy, kasztelan lubelski, podkomorzy lubelski); Księga ławnicza miasta Płocka, nr 113 (1499 r. - rajca, Maciej Fuśnik). W obecności litkupników dokonywano także spłaty wierzytelności, ibidem, nr 107 (1499 r.). Por. Ch. McNall, „Litkup” in the Rural Court Books of Old-Time Poland, CPH 49, 1997, 1-2, s. 11-25.

${ }^{76}$ Księgi sądowe miasta Wąwolnicy, nr 199 (1495 r.), 208 (1496 r.).

77 M.in. Księga sądowa wsi Wary 1449-1623, oprac. L. Łysiak, Wrocław 1971, nr 6, 62 (1466 r.), 75 (1471 r.) i passim; Księgi gromadzkie wsi „Maszkienice” 1482-1602, w: Księgi sądowe wiejskie, t. 1, wyd. B. Ulanowski, Kraków 1921, nr 525 (1485 r.) i passim.

${ }_{78}$ Księgi sądowe miasta Wąwolnicy, nr 158 (1494 r.), 166, 172, 173, 174, 175, 176 (1495 r.), 212, 214, 215, 234 (1497 r.), 253 (1499 r.), 266, 267 (1500 r.). 
ona w domu czy karczmie. Najprawdopodobniej decydowała o tym któraś ze stron, chociaż w niektórych miastach (Lublin) urzędowe potwierdzenie transakcji i wpis do księgi były wymagane przez władze miejskie ${ }^{79}$.

\section{Testament - napięcie między oralnością a piśmiennością}

Suwerenną decyzję klienta sądu stanowiło natomiast postanowienie o sporządzeniu na piśmie aktu ostatniej woli. „Tworzenie testamentu, a więc komponowanie tekstu i spisywanie go (lub wpisywanie do specjalnych ksiąg), należy widzieć jako skomplikowany i pasjonujący proces, który odsłania mechanizmy piśmienności pragmatycznej. Determinacja utrwalenia ostatniej woli nakładała się w tym procesie na głębokie pokłady komunikacji oralnej, rejestrowanej lub z różnych powodów kreowanej sztucznie w tekście pisanym..." ${ }^{80}$.

Akty ostatniej woli przetrwały do naszych czasów w bardzo różnej formie $^{81}$, a zachowane przekazy źródłowe odzwierciedlają tę rozmaitość i pokazują różne procedury towarzyszące ich sporządzaniu. Informacje zawarte $\mathrm{w}$ tekstach pisanych i przekazy ikonograficzne pozwalają nam plastycznie wyobrazić sobie akt sporządzania testamentu przez osobę chorą. Była to uroczystość, w której udział brał testator, członkowie jego rodziny, przynajmniej dwóch świadków, przyszłych egzekutorów postanowień, czasami poświadczona jest obecność duchownego, wreszcie uczestniczył w tym spotkaniu skryba, choć on akurat nie zawsze był niezbędny. Nie możemy też zapominać o urzędnikach miejskich, których zadaniem było uwierzytelnienie dyspozycji ostatniej woli, np. oddelegowanych w tym celu przedstawicielach rady czy ławnikach odbywających przy łożu chorego sąd konieczny. Czasami jednak wystarczała tylko obecność rodziny i świadków. Jak słusznie podkreśla Katalin Szende, spoczywała na nich odpowiedzialność za wierne przekazanie słów testatora. „Dlatego dobór świadków był sprawą, na którą zwracały uwagę przepisy prawne i którą traktowano poważnie w codziennej praktyce"82.

79 Lublin, nr 849 (1470 r.).

80 A. Adamska, „Stąd do wieczności”. Testament $w$ perspektywie piśmienności pragmatycznej na przełomie średniowiecza i epoki nowożytnej, KHKM 61, 2013, 2, s. 191.

${ }^{81}$ Więcej na ten temat: A. Bartoszewicz, Piśmienność mieszczańska, s. 250-255. Por. też Testamenty z ksiag sądowych małych miast polskich do 1525 roku, oprac. A. Bartoszewicz, K. Mrozowski, M. Radomski, K. Warda, red. A. Bartoszewicz, Warszawa 2017, s. 20-24.

${ }^{82} \mathrm{~K}$. Szende, Testamenty i ustne oświadczenia woli. Oralność i piśmienność w procesie sporządzania testamentów na Węgrzech w późnym średniowieczu, KHKM 61, 2013, 2, s. 226-227. 
Przekazy pisemne, którymi dysponujemy, prezentują nam często tylko drobne elementy tego wydarzenia. Forma i treść najstarszych zapisek informujących o wyrażeniu dyspozycji ostatniej woli sugeruje zresztą, że było to przede wszystkim wydarzenie odbywające się w sferze kultury żywego słowa, a w wielu wypadkach na piśmie utrwalano tylko niektóre najważniejsze postanowienia testatora, niekiedy już po jego śmierci, na podstawie zeznań świadków ${ }^{83}$. Większość testamentów, niezależnie od okoliczności towarzyszących ich powstaniu i formy, w jakiej przetrwały do naszych czasów, ma zresztą lakoniczny, formularzowy charakter. Tylko wyjątkowo zawierają one bezpośrednie informacje o słowach wypowiadanych przez ludzi biorących udział w akcie spisywania ostatniej woli. Dlatego warto zwrócić uwagę na testament mieszczanina z Kleparza, Wojciecha Raka ${ }^{84}$. Ten akt ostatniej woli został spisany w czerwcu $1506 \mathrm{r}$. w czasie zwołanego w tym celu posiedzenia sądu koniecznego i zawiera opis dialogu, który odbył się między testatorem a jego rodzicami. Jak informuje nas wpis do kleparskiej księgi ławniczej „testator skierował te lub podobne [wyróżnienie - A.B.] słowa do swego ojca: «Ojcze, wiesz, że nic od ciebie nie otrzymałem, tak samo od mojej matki, tak samo od innych krewnych. Dlatego pytam cię, czy rzeczy, które mam jako własne mogę przeznaczyć tak, jak tego chcę». I ten [ojciec] odpowiedział: «możesz mój synu»" ${ }^{55}$. W drugiej kolejności testator za pośrednictwem Andrzeja, byłego ratusznego, swego rzecznika, zwrócił się z takim samym pytaniem do sądu. Dopiero po uzyskaniu pozytywnej odpowiedzi został sporządzony zapis testamentowy.

Można przypuszczać, że obecność krewnych przy spisywaniu aktu ostatniej woli była niezbędna i potwierdzała ich akceptację dla postanowień, często naruszających normy prawa zwyczajowego. Trudno powiedzieć, czy zawsze oczekiwano od nich także słownej deklaracji, aczkolwiek zapis w testamencie Wojciecha Raka nie jest jedynym

Roli świadków dowodzą występujące w miejskich księgach sądowych zapisy treści testamentów sporządzone na podstawie ich zeznań, np. AGAD, Varia archiwalne z Biblioteki Baworowskich, sygn. 252, Księga wójtowska Lanckorony, k. 14 (1498 r.), 75v.-76 (1508 r.); BC, rkps 2981, Księga ławnicza Przeworska, s. 253 (1468 r.).

${ }^{83}$ Przykładem może być zapiska w księdze pleszewskiej: „uczciwa śp. pani wójtowa w obliczu śmierci dla zbawienia swej duszy zapisała w testamencie 1 grzywnę na swym domu na kościół św. Jana Chrzciciela", Najdawniejsze zapiski z księgi miejskiej Pleszewa, nr 12 (1431 r.).

${ }^{84}$ ANK, Archiwum miasta Kleparza, sygn. 1, s. 87-89.

85 „Item dictus testator ad patrem suum hec vel his similia verba protulit: «Pater, scis quod ego nichil a te habeo, neque a matre mea, neque etiam ab aliquibus consanguineis. Ideo te interrogo utrum ego mea bona que habeo tamquam propria possum convertere ubi voleo». Et ipse respondit: «potest fili mei [s]»", ibidem. 
źródłem poświadczającym takie działanie. Na przykład w testamencie Stanisława, młynarza z Koła, zachowała się wzmianka o oświadczeniu złożonym przez bratanice testatora, zrzekające się praw do jego majątku ${ }^{86}$. Podobnie jedna z not w księdze ławniczej krakowskiej wskazuje, że sporządzeniu wpisu towarzyszyły wypowiedzi poświadczające prawo testatora do dysponowania swym majątkiem: „Stano Streicher rajca zdrowy na ciele i umyśle, pytając czy może dysponować zdobytymi przez siebie dobrami, ustnie uczynił przed nami swój testament i ostatnią wolę, w ten sposób, jak zostało to zapisane" ${ }^{\text {87 }}$. Widzimy zatem pewien rytuał, który towarzyszył sporządzeniu zapisu w księdze, obejmujący wypowiadanie przez testatora i członków jego rodziny stosownych formuł. Przytoczone przykłady pokazują, że nie dotyczyło to wyłącznie aktu odbywającego się w domu chorego. Także spisanie (lub uwierzytelnienie) ostatniej woli przez osobę zdrową, występującą samodzielnie przed sądem, miało szczególną oprawę i wymagało obecności określonych osób i konkretnych, ustnych wypowiedzi.

Warto zwrócić uwagę na jeszcze jedno zjawisko. Już w drugiej połowie $\mathrm{XIV}$ w. istniała grupa testatorów - w dużych miastach, przede wszystkim Krakowie - stająca przed urzędnikami z gotowym tekstem swej ostatniej woli spisanym na osobnych kartach papieru (cedula, czedil). Mieszczanin krakowski Piotr Tarnow miał przy tym wypowiedzieć takie słowa: „Drodzy panowie. Oto moja ostatnia wola i proszę was, żebyście wpisali ją do waszej księgi"88. Z kolei akt ostatniej woli Katarzyny Cloze, także mieszkanki Krakowa, rozpoczynają słowa: „Przed wami szanowni, drodzy panowie czynię mój testament i moją ostatnią wolę, tak jak została zapisana na tej karcie" ${ }^{99}$. Inna wzmianka zachowana w krakowskiej Liber

${ }^{86}$ KDW, t. 9, nr 1370 (1434 r.). Więcej o tym dokumencie: T. Związek, Testament młynarza z Koła. Przyczynek do badań nad późnośredniowiecznym młynarstwem na ziemiach polskich, „Średniowiecze Polskie i Powszechne” 5 (9), 2012, s. 154-169.

87 „Her Stano Streicher der Ratman keiginwortiglich steende gesunt des lebes und mit Wolbedochtem mute frogende im rechten ap her mit seyme wolgewonnen gute tun und lossen mocht noch seyme willen und von uns hyroff sulche ortilliche bestetigunge seyn Testament und schickunge seynes leczten willens vor uns gemacht in sulcher weyse alz hy noch stet geschreben", ANK, Akta miasta Krakowa, sygn. 6, s. 174 (1439 r.). Podobnie, ibidem, s. 188 (1439 r.), 195 (1440 r.), 263 (1442 r.); ibidem, sygn. 8, s. 76 (1461 r.).

88 „Lieben Herren. Das ist meyn leczte wille und ich bite euch daz ihr das in ewer buch schreyben", ibidem, sygn. 428, s. 319 (1433 r.). Podobnie w testamencie Franczka Neorzy z 1434 r.: „Her Richter und liben hern, das ist meyn leczter wille ap got an mir ich tut", ibidem, sygn. 6, s. 81. Podobnie m.in. ibidem, sygn. 772, s. 31 (1451 r.), 126 (1481 r.) i passim.

89 „von Euch Ersamen lieben Herren mache ich mein Testament und mein lecztin willin also alz do geschribin wird in desir czedil", ibidem, sygn. 772, s. 6 (1443 r.). 
testamentorum wskazuje, że testamenty przedstawiane na kartkach papieru były odczytywane - zapewne przez miejskiego pisarza - rodzinie ${ }^{90}$. Niekiedy spisany na kartce tekst uzupełniano ustnymi dyspozycjami. Gdy krakowianin Paweł Homan przedstawił sądowi ławniczemu testament spisany na kartce papieru, do księgi wpisano jego treść, po czym pisarz zanotował: „takie są słowa wspomnianej karty, potem [testator] wybrał wykonawców swej ostatniej woli..." ${ }^{\prime 1}$.

Warto zastanowić się nad mechanizmem powstania i charakterem owych kart z tekstami ostatniej woli przedstawianymi ławnikom przez testatorów. Podstawowe pytanie brzmi, kto był pisarzem tych tekstów i w jakich okolicznościach je spisywano. Czy towarzyszyła im procedura analogiczna do tej odbywającej się przy łożu chorego, czy w trakcie wpisywania do księgi ustnego zeznania? Informacje zawarte $\mathrm{w}$ akcie ostatniej woli Jana Szultisa, przepisanym z karty do krakowskiej księgi testamentów, pozwalają stwierdzić obecność minimum czterech świadków, w tym burmistrza, pełniącego jednocześnie rolę egzekutora, oraz żony testatora, która wyraziła zgodę na postanowienia jego ostatniej woli ${ }^{92}$. W wielu innych testamentach spisanych in cedula jednak nie znajdujemy bezpośrednich informacji potwierdzających, że testament został spisany w obecności krewnych, sąsiadów czy miejskich urzędników. Jeśli wyznaczeni zostali egzekutorzy ostatniej woli, tak jak np. w testamencie kuśnierza krakowskiego Jana Kumszy ${ }^{93}$, możemy domyślać się ich obecności podczas redagowania i spisywania dyspozycji. Część testamentów nie zawiera jednak żadnych wzmianek pozwalających zrekonstruować okoliczności sporządzania zapisów ${ }^{94}$, pewną wskazówkę może stanowić jednak analiza ich treści. Niektóre z nich robią wrażenie dyktowanych z pamięci, w sposób chaotyczny, przez osobę przypominającą sobie na bieżąco o długach, wierzytelnościach czy legatach ${ }^{95}$. W innych wypadkach

90 „Also was der laut der obgenannte czedil und testamentis und dy obgennante fraw Helena seyne hausfraw hot personlich voryowort in das obgenennte testament", ibidem, sygn. 772, s. 31 (1451 r.).

91 „Hec sunt verba cedule predicte post hoc elegit sibi executores huius sue voluntatis et disposicionis, Goyhardum Strol et Petrum Graser scabinum”, ibidem, sygn. 5, s. 79 (1423 r.).

92 Ibidem, sygn. 772, s. 31 (1451 r.).

93 Ibidem, s. 126 (1481 r.).

94 Np. testament Katarzyny Close, ibidem, s. 6 (1443 r.).

$95 \mathrm{~Np}$. notariusz publiczny i pisarz miejski płocki notujący ostatnią wolę tamtejszego mieszczanina Bartłomieja Kawki zapisał, że testator nie określił sumy, którą są mu winni za wełnę dwaj kupcy toruńscy (,pro lana summam non expressit”), Księga ławnicza miasta Płocka, nr 61 (1495 r.). Ten testament posiada jednak przejrzystą strukturę wewnętrzną, zapisy są pogrupowane tematycznie, nie wiemy, czy takiego podzia- 
widoczne jest, że testator korzystał przy sporządzaniu aktu swej ostatniej woli z pisemnej pomocy w postaci rejestrów handlowych, listów zastawnych czy może wcześniejszych wersji testamentu. Język, forma i styl tych zapisów nie są spójne, a całe partie tekstu robią wrażenie skądś przepisanych. To wrażenie potwierdza przypadek mieszczanina kleparskiego Jana Waliszowskiego, który sporządzał swój testament podczas zebrania sądu koniecznego. Częścią tych działań było przedstawienie rejestru handlowego. Jego treść została publicznie odczytana przez notariusza publicznego, a następnie testator potwierdził swoje długi ${ }^{96}$.

Relacje między łaciną a językami wernakularnymi

Zadaniem pisarza dokonującego wpisu w księdze było wtłoczenie słów wypowiedzianych i odczytanych - oraz gestów w formularzowe ramy. Wymykają się temu - w niewielkim stopniu - wpisy o charakterze protokolarnym, w których przytaczano słowa wypowiedziane przez uczestników wydarzenia mającego miejsce coram iudicio. Cały czas musimy jednak mieć świadomość, że mamy do czynienia z przekazem pisarza, który notował hec vel his similia verba. Raczej similia verba, szczególnie w przypadkach łacińskiego opisu wernakularnych działan' ${ }^{97}$.

Jednym z zabiegów służących poznaniu relacji między wernakularną kulturą żywego słowa a łacińskim zapisem jest analiza użytych przez pisarza słów w języku rodzimym. Pomagają one wniknąć w naturę komunikacji mającej miejsce przed sądem, zawierając słowa i frazy, które wydają się być zaczerpnięte prosto z mówionego oryginału ${ }^{98}$. Słowa i wyrażenia wernakularne spotykamy w tekstach łacińskich w całej Europie. Ich zakres znaczeniowy jest wszędzie bardzo podobny. $\mathrm{W}$ języku rodzimym pisarze notowali nazwy osobowe i miejscowe, terminy prawne oraz różnego rodzaju określenia związane z życiem codziennym, działalnością rolniczą bądź rzemieślniczą ${ }^{99}$. Za każdym razem

łu dokonał pisarz ex post, czy może w trakcie spisywania testamentu zadawał pytania, pomagając testatorowi uporządkować dyspozycje. O tym aspekcie spisywania aktów ostatniej woli: J. Majorossy, Archiwa zmarłych. Administrowanie aktami ostatniej woli w miastach węgierskich późnego średniowiecza, KHKM 61, 2013, 2, s. 243.

96 ANK, Archiwum miasta Kleparza, sygn. 1, s. 127-130 (1508 r.).

97 Aczkolwiek teksty notowane w językach rodzimych także podlegały przetworzeniu przez pisarzy.

98 Por. A. Butcher, op. cit., s. 300-301.

99 A. Adamska, Od łaciny do języków wernakularnych. Język dokumentu średniowiecznego $w$ świetle nowszych badań, w: Kultura pisma $w$ średniowieczu. Znane problemy, nowe metody, red. A. Adamska, P. Kras, Lublin 2013, s. 58; A. Butcher, op. cit., s. 300-301. 
za ich pomocą możemy odtworzyć jakiś okruch działań przeprowadzonych w języku rodzimym. Nazwy miejscowe i osobowe (Małomięsko, Wołek, Głuchy, Liczygroch, Odrzykoń, Ząbek, Czapka ${ }^{100}$ ) pozwalają prześledzić, jak poszczególni pisarze radzili sobie z pisownią wyrazów w języku polskim. Dzięki wernakularnym formom imion („Andreas alias Jandrika"101) możemy zobaczyć, jakie nazwy osobowe faktyczne funkcjonowały i poznać jeden z mechanizmów ich tworzenia. Wernakularna pisownia imion typu „Loryncz”, „Woytek”, „Plona”102 dowodzi też, jak sztucznym tworem były łacińskie formy imion zanotowane $\mathrm{w}$ księgach i dokumentach.

Godne uwagi są zapisane w języku rodzimym wyrazy i wyrażenia związane z życiem codziennymi klienteli sądów miejskich. Używanie przez pisarza tego typu określeń jest zazwyczaj oceniane przez badaczy jako oznaka niewydolności funkcjonalnej łaciny, niezdolnej do oddania precyzji terminologii ważnych dziedzin życia społecznego, jaką zapewniało słownictwo wernakularne ${ }^{103}$. Polski wyraz stanowił często tłumaczenie i zarazem uzupełnienie łacińskiego terminu: „domum submuro alias wykusch”, „liberavit alias wyszwala”, „pro dotalicio alias zawyano”, "mensam alias yadky" ${ }^{104}$. Czasami ta skrupulatność pisarza jest wręcz rozczulająca i pokazuje, że chyba rzeczywiście brakowało mu łacińskich odpowiedników: „resignavit domum suam alias sgnyly” ${ }^{105}$, „percussit et wulgariter mordowal" ${ }^{106} . \mathrm{Z}$ analogiczną sytuacją mamy do czynienia przy określaniu pokrewieństwa ${ }^{107}$. Tego rodzaju wyrazy w języku rodzimym występują często bez łacińskiego odpowiednika. Podobnie jest także w wypadku nazw towarów kupieckich, sprzętów domowych,

100 Warta 1, passim.

101 Warta 1, s. 147 (1489 r.).

102 Archiwum Państwowe w Poznaniu, Akta miasta Poniec, sygn. I/17, s. 1-16 (1468-1483). Liczne przykłady wernakularnych wersji imion znajdują się także m.in. w poznańskiej księdze ławniczej z lat 30. XV w., ibidem, Akta miasta Poznania, sygn. I. 291, passim.

103 A. Adamska, Od łaciny do języków wernakularnych, s. 58.

104 Przykłady z księgi wójtowsko-ławniczej lubelskiej za: M. Resztak, Ze studiów nad kultura prawna kancelarii miejskiej późnośredniowiecznego Lublina, w: Coram iudicio. Studia z dziejów kultury prawnej w miastach późnośredniowiecznej Polski, red. A. Bartoszewicz, Warszawa 2013, s. 109-125 (tam szczegółowa analiza występowania jęz. polskiego w lubelskiej księdze ławniczej).

${ }^{105}$ Księgi sądowe miasta Wąwolnicy, nr 10.

106 ANK, Akta miasta Kazimierza, sygn. K378, k. 60v., 65v.

107 Np. określenia występujące w księdze ławniczej Nowej Warszawy: „pasirzb”, „oczczim”, „wnuk”, „gener alias ząncz”, „swak”, „sorori alias pyrodnej”, „szurzy”, „dzyevyerz”, Nowa Warszawa, według indeksu. 
ubrań czy materiałów, z jakich były wykonane ${ }^{108}$. Przykładem problemów translatorskich miejskich pisarzy są określenia miar powierzchni. Występują one niemal we wszystkich księgach miejskich, są bardzo różnorodne i dowodzą pewnej bezradności pisarzy szukających stosownego łacińskiego terminu dla polskiego wyrazu. W rezultacie tych zmagań polskie słowo „pręt” w jednej tylko księdze ławniczej Nowej Warszawy zostało przetłumaczone na łacinę jako mensura, iuger, pars i virga ${ }^{109}$. Z kolei w księdze wójtowsko-ławniczej Warty łacińskie słowo sulcum oznacza wernakularne „zagon”, „lech”, „skład”110. Ten ostatni termin oddawało także łacińskie słowo bicampicus, używane również w znaczeniu „źreb”111.

Słów i wyrażeń w języku polskim nie używano konsekwentnie, a ich obecność częściej notujemy w zapiskach sporządzonych przez pisarzy przygodnych, często przez tych nie najlepiej obytych z łacińską ars dictandi. Jednak nie możemy wykluczyć, że przyczyną zapisania określonych wyrazów w języku rodzimym mogła być też potrzeba podania najistotniejszej treści danego wpisu w języku zrozumiałym dla strony procesowej ${ }^{112}$. Mogło tak być zwłaszcza w wypadku, gdy dobrze wykształceni profesjonaliści pióra podawali w języku polskim określenia dotyczące procedur sądowych mające swoje precyzyjne, łacińskie odpowiedniki, bez wątpienia dobrze znane pisarzowi, ale nie stronom procesu ${ }^{113}$.

108 „quatuor pulmaticas, due puchowe, due perszne”, M. Resztak, op. cit., s. 122 (tam też inne przykłady z księgi lubelskiej). Zob. też listę wyrazów polskich w wyrokach sądu magdeburskiego w Krakowie: J. Matuszewski, Inkrustacje polskie w wyrokach łacińskich najwyższego sądu magdeburskiego grodu krakowskiego, CPH 47, 1995, 1/2, s. 187-199; idem, Jeszcze raz: inkrustacje polskie w wyrokach łacińskich najwyższego sądu magdeburskiego grodu krakowskiego, „Studia z Dziejów Państwa i Prawa Polskiego” 4, 1999, s. 109-120.

109 Nowa Warszawa, według indeksu.

110 „Unum sulcum orti alias lecha”, „sulcum alias zagon”, ”duos sulcos alias dwa wsklady”; „pro duabus sulcis alias lechi”, Warta 1, s. 50, 93, 151, 156, 159.

111 „duabus bicampicis alias sklady” (ibidem, s. 93); „medium bicampice alis sszeby" (ibidem, s. 108). O problemach, jakie powoduje różnorodność określeń miar powierzchni: A. Dunin-Wąsowicz, Pomiary gruntu w Koronie w XVI-XVIII wieku. Próba ustalenia wielkości ról na ziemiach polskich, Warszawa 1994, s. $61 \mathrm{nn}$.

112 H. Samsonowicz, op. cit., s. 324-325; A. Bartoszewicz, U progu społeczeństwa obywatelskiego. Warszawskie sądownictwo samorzadowe w późnym średniowieczu, „Rocznik Warszawski" 36, 2008, s. 97-98. Zob. też A.J. Guriewicz, Język źródła i rzeczywistość społeczna. Średniowieczny bilingwizm, St. Źr. 18, 1973, s. 1-13, na temat konieczności opisywania świata za pomocą pojęć częściowo lub całkowicie nieodpowiadających rzeczywistości.

$113 \mathrm{~Np}$. „super preposicionem alias przypowesz”, Księga ławnicza miasta Płocka, nr 47 (1495 r.); podobnie: ibidem, s. 92 (1498 r.), 124 (1500 r.). 
Rytualna oprawa działań rady miejskiej

Spektakl, który odbywał się przed sądem ławniczym, niejednokrotnie znajdował ciąg dalszy przed obliczem rady miejskiej ${ }^{114}$. Funkcjonowanie tej instytucji także miało w sobie wiele $\mathrm{z}$ theatrum, zwłaszcza w wypadku wielkich ośrodków ${ }^{115}$. W mniejszych miastach oprawa i ceremoniał towarzyszący posiedzeniom rajców siłą rzeczy musiały być skromniejsze, ale zawsze budziły duże zainteresowanie. Gdy np. czytamy, że posiedzenia rady w Pleszewie odbywały się przed domem burmistrza, możemy się domyślać, że działo się to w obecności licznej publiczności ${ }^{116}$, która chciała wziąć udział w tym wydarzeniu. Teatralny charakter miały wybory władz miejskich, a także przysięgi składane przez rajców, ławników czy pisarza, podobnie jak procedura przyjmowania przybyszy do prawa miejskiego. Mamy prawo przypuszczać, że relacje między gestem, słowem mówionym - słuchanym a pisanym były podczas posiedzeń rady podobne jak w wypadku posiedzeń ławy. Pewne różnice możemy jednak zaobserwować. Wydaje się, że niejednokrotnie załatwienie sprawy przed rajcami było sprawniejsze, krótsze, nie wymagało aż tylu proceduralnych działań. Analiza zapisek w księgach miejskich ośrodków, dla których zachowały się zarówno akta rady, jak i ławy pokazuje, że analogiczne czynności prywatnoprawne uwierzytelniano przed jednym i drugim urzędem. $\mathrm{Na}$ pewno część udających się do rajców nie chciała lub nie mogła czekać na przewidziane przepisami posiedzenie ławy. Być może przynajmniej dla niektórych klientów urzędu radzieckiego przyspieszenie procedury było atrakcyjne, a rezygnacja z elementów spektaklu właściwego sądom ławniczym w niczym nie przeszkadzała. W tym miejscu można przywołać przykład Krakowa, gdzie większość występujących przed radą stanowili przedstawiciele patrycjatu, m.in. kupcy, zainteresowani uwierzytelnieniem swoich działań wpisem w księdze. Byli to ludzie obyci $\mathrm{z}$ pismem w swej codziennej pracy, sami prowadzili księgi i rejestry

${ }^{114} \mathrm{~Np}$. w Wąwolnicy rajcy przyjmowali relację podwójciego bądź ławników na temat spraw toczących się przed sądami gajonymi, Księgi sądowe miasta Wąwolnicy, nr 14 (1488 r.), 17 (1482 r.), 54, 55, 57 (1486 r.), 59 (1487 r.).

115 Gerd Althoff traktuje rady miejskie jako „główny generator” rytuałów, idem, Potega rytuału. Symbolika władzy w średniowieczu, Warszawa 2012 (oryg. niem. 2003), s. 157. Tam też wcześniejsza literatura przedmiotu. O ceremoniach towarzyszących wyborowi rajców oraz o znaczeniu posiedzeń rady, m.in. na podstawie zapisek w poznańskiej księdze radzieckiej: D.W. Poeck, Rituale der Ratswahl. Zeichen und Zeremoniell der Ratssetzung in Europa (12.-18. Jahrhundert), Köln 2003, s. 250-251 i passim. Por. też M. Wyżga, Ceremonie na ratuszu krakowskim w XV-XVIII wieku, RDSG 74, 2014, zwłaszcza s. 145-146.

${ }^{116}$ Najdawniejsze zapiski z księgi miejskiej Pleszewa, nr 4 (1428 r.), 18 (1429 r.). 
lub mieli zajmujących się tym pracowników, a zatem akt sporządzania zapiski nie miał dla nich większego znaczenia, nie stanowił rytualnej czynności wspomagającej pamięć. Przeciwnie, miał ściśle pragmatyczny, biurokratyczny charakter.

\section{Uwagi końcowe}

Każda zapiska zachowana w księgach miejskich urzędów, nawet najbardziej lakoniczna, posiada swoją werbalną i wizualną historię. Stanowi efekt różnego rodzaju działań odbywających się w sferze słów i gestów, słuchanych, oglądanych i wreszcie przetworzonych przez pisarza w urzędowy zapis. Analiza poszczególnych ksiąg i notek pozwala w pewnym stopniu - na ogół nie do końca satysfakcjonującym - stwierdzić umiejętności pisarza i okoliczności sporządzenia zapisu. Już na pierwszy rzut oka możemy zaobserwować, czy pisarz działał pospiesznie i bez większego namysłu, czy staranie kaligrafował wpis i dobierał odpowiednio wyszukane słowa. Potrafimy też bez trudu stwierdzić, czy zapiska ma charakter brulionowy, czy czystopisowy. Kolejne pytania dotyczą tego, czy spisano ją w trakcie ceremoniału urzędowego, czy zredagowano później. Czy zapiska składa się tylko z podstawowych formularzowych treści, czy podano więcej informacji? Wnikamy dzięki temu nie tylko w metody pracy pisarza, ale także w sposób funkcjonowania urzędu, jego obyczaje i rytuał towarzyszący różnego rodzaju działaniom. Ich teatralny charakter i chęć przekazania obecnym, stronom i świadkom, zrozumiałego komunikatu za pomocą różnorakich środków wyrazu nie budzą żadnych wątpliwości ${ }^{117}$. Badając zmiany zachodzące w relacjach między pismem a kulturą żywego słowa w późnośredniowiecznych miastach, powinniśmy jednak zastanowić się, czy i w jakim stopniu zapiski w księgach radzieckich i ławniczych uwzględniają rytualne działania, zarówno te określone przez przepisy prawa miejskiego, jak i te dziejące się poza urzędem, towarzyszące czynności później rejestrowanej poprzez wpis do akt. Wiąże się z tym kolejne pytanie dotyczące powodów zarejestrowania na piśmie takich a nie innych działań, mechanizmu sporządzania zapiski, ogłaszania - może też konsultowania - jej treści, wreszcie późniejszego jej użytkowania. Wreszcie musimy się zastanowić nad tym, w jaki sposób słowo pisane, sporządzanie i odczytywanie notek i dokumentów, zaczynało stawać się elementem urzędowego rytuału i jak wpływało na jego zmiany.

117 Por. analizę pod tym kątem dzieł B. Groickiego, K.A. Marciniak, op. cit. 
Niniejszy artykuł stanowi próbę pokazania, na ile odpowiedź na te wszystkie pytania jest możliwa, do jakiego stopnia jesteśmy w stanie odtworzyć relacje między kulturą pisma a żywego słowa na podstawie zachowanego materiału źródłowego. Wzrastająca od początku XV w. liczba zapisek w księgach miejskich i wzrost liczby ośrodków, z których one pochodzą powoduje, że wbrew pozorom dysponujemy relatywnie bogatym materiałem źródłowym, aczkolwiek posiadającym różną wartość badawczą. Jego wstępna analiza dowodzi, że w wypadku mniejszych ośrodków mamy w XV w. do czynienia ze stopniowym wzrostem znajomości przepisów prawa miejskiego i równocześnie z rozbudowywaniem ceremoniału towarzyszącego działaniom urzędów. Można chyba zaryzykować postawienie hipotezy, że różne formy urzędowego theatrum, podobnie jak dokument pisany, księga kancelaryjna czy kodeks prawny, były narzędziami, przy których pomocy miejskie elity oddziaływały na pozostałych mieszkańców miasta. W ten sposób umacniano autorytet prawa miejskiego i równocześnie miejskich urzędników, przede wszystkim wobec tych mieszkańców miasta, którzy ze słowem pisanym stykali się rzadko, w kościele bądź urzędzie. Inaczej sądowe ceremoniały postrzegali ludzie należący do elit finansowych i urzędniczych. W miastach większych, liczących minimum 2-2,5 tys. mieszkańców, zaczynamy od drugiej połowy XV w. (w największych ośrodkach wcześniej) obserwować tworzenie się kręgów, dla których pismo stanowiło podstawowe narzędzie komunikacji i utrwalania informacji. Dla nich czasochłonne, teatralne urzędowe procedury w wypadku codziennych, rutynowych działań, przede wszystkich związanych z handlem i kredytem, stawały się w coraz większym stopniu uciążliwe. Tę roboczą hipotezę potwierdzić mogą jednak dopiero dalsze badania i szczegółowa analiza zachowanych ksiąg miejskich pod kątem interesującego nas zagadnienia. Wtedy dopiero wysuwanie bardziej ogólnych, całościowych wniosków można będzie uznać za uprawnione, ponieważ każda z zachowanych ksiąg miejskich posiada indywidualne cechy. $Z$ jednej strony pokazuje to różne aspekty problemu, z drugiej dowodzi, że relacje między kulturą pisma a żywego słowa zależały od bardzo wielu czynników i w różny sposób się kształtowały w poszczególnych miastach.

\section{Streszczenie}

Każda zapiska zachowana w księgach miejskich stanowi efekt różnego rodzaju działań odbywających się w sferze słów i gestów, słuchanych, oglądanych i wreszcie przetworzonych przez pisarza w urzędowy zapis. Niniejszy artykuł stanowi 
próbę odpowiedzi na pytanie, jakie miejsce w tym świecie teatralnych gestów i utartych formuł zajmowało pismo. Punkt wyjścia stanowią przekazy źródłowe dotyczące pozawerbalnych środków przekazu w świetle tekstów normatywnych. Kolejne problemy, to kwestia, czy i w jakim stopniu zapiski urzędowe uwzględniają różne rytualne działania oraz pytanie dotyczące powodów zarejestrowania danych czynności, mechanizmu sporządzania zapiski, ogłaszania jej treści i późniejszego jej użytkowania. Musimy się też zastanowić nad tym, w jaki sposób sporządzanie i odczytywanie notek i dokumentów stało się elementem urzędowego rytuału i jak wpływało na jego zmiany. Istotna jest także kwestia słów w językach rodzimych pomagających wniknąć w naturę komunikacji mającej miejsce przed sądem. Ostatnia część artykułu dotyczy rytualnej oprawy działań rady miejskiej.

Wzrastająca od początku XV w. liczba zapisek sądowych powoduje, że dysponujemy relatywnie bogatym materiałem źródłowym, aczkolwiek posiadającym różną wartość badawczą. Jego wstępna analiza dowodzi, że w wypadku mniejszych miast mamy do czynienia z powolną recepcją pisma, pełnieniem przez nie funkcji pomocniczych i równocześnie z rozbudowywaniem ceremoniału towarzyszącego działaniom urzędów. W miastach większych (minimum 2-2,5 tys. mieszkańców) zaczynamy z kolei obserwować tworzenie się elitarnych kręgów, dla których pismo było podstawowym narzędziem komunikacji i utrwalania informacji, a czasochłonne, teatralne procedury stawały się w coraz większym stopniu uciążliwą przeszkodą.

\section{Talk, gesture, writing. Relations between the culture of the living word and the culture of writing in the light of records in judicial registers of late medieval Polish towns}

Each record registered in municipal registers is a result of many actions in the sphere of words and gestures, listened to, seen, watched, and finally transformed by the scribe into an official registration. The present article attempts to answer the question about the place occupied by writing in that world of theatrical gestures and set phrases. The starting point are historical sources relating to extraverbal means of communication in the light of normative texts. Another problem is the question whether (and if, to what extent) official records allowed for various ritual actions, and why those actions were registered, what was the mechanism of registering the record, of announcing its content and its further use. The next issue to consider is in what way the actual act of registering and reading of records and documents became part of an official ritual and how it influenced its changes. Also important is the question of words in vernacular languages making it possible to probe the nature of communication takin place in the court. The closing part of the article is devoted to the ritual setting of operations of the municipal council.

Owing to the fact that from the early fifteenth century onwards, the number of court registers increased, we have relatively rich source material at our disposal, although of varying research value. Its initial analysis indicates that in smaller towns there was a gradual reception of writing, which performed auxiliary functions, and this process was accompanied by the parallel development of the 
ceremonial of the office activity. In larger towns and cities (with minimum of two, or two and a half thousand inhabitants) we can observe the gradual creation of elite circles, for whom writing was a basic means of communication and of preserving information, and time-consuming, theatrical procedures were becoming more and more burdensome.

Translated by Grażyna Waluga

\section{Bibliografia}

Adamska Anna, „Czy Pan wie, kto ja jestem?” Kilka uwag o mechanizmach percepcji wzrokowej i skuteczności kodów westymentarnych w późnośredniowiecznej Europie, w: Habitus facit hominem. Spoteczne funkcje ubioru w średniowieczu i w epoce nowożytnej, red. Ewa Wółkiewicz, Monika Saczyńska, Marcin R. Pauk, Instytut Archeologii i Etnologii PAN, Warszawa 2016, s. 19-34.

Adamska Anna, Od łaciny do języków wernakularnych. Język dokumentu średniowiecznego $w$ świetle nowszych badań, w: Kultura pisma w średniowieczu. Znane problemy, nowe metody, red. Anna Adamska, Paweł Kras, KUL, Lublin 2013 (seria: „Colloquia Mediaevalia Lublinensia" II), s. 51-99.

Adamska Anna, „Stąd do wieczności”. Testament w perspektywie piśmienności pragmatycznej na przełomie średniowiecza i epoki nowożytnej, KHKM 61, 2013, 2, s. 185-200.

Bartoszewicz Agnieszka, Piśmienność mieszczańska w późnośredniowiecznej Polsce, Wydawnictwa UW, Warszawa 2012.

Butcher Andrew, Textual Production and Vernacular Behaviour: Locating a Fifteenth-Century Administrative Book, w: Vernacularity in England and Wales, c. 1300-1550, red. Elizabeth Salter, Helen Wicker, Brepols, Turnhout 2011 (seria: „Utrecht Studies in Medieval Literacy" t. 17), s. 295-324.

Duda Michalina, Jóźwiak Sławomir, Ze świata średniowiecznej symboliki. Gest i forma przysięgi w chrześcijańskiej Europie (X-XV w.), Universitas, Kraków 2014.

Dunin-Wąsowicz Anna, Pomiary gruntu w Koronie w XVI-XVIII wieku. Próba ustalenia wielkości ról na ziemiach polskich, IH PAN, Warszawa 1994.

Majorossy Judit, Archiwa zmarlych. Administrowanie aktami ostatniej woli w miastach węierskich późnego średniowiecza, KHKM 61, 2013, 2, s. 239-250.

Marciniak Kamila A., Proces sadowy jako theatrum w świetle dzieł Bartłomieja Groickiego, CPH 68, 2016, 1, s. 149-178.

Mikołajczyk Marian, Proces kryminalny w miastach Małopolski XVI-XVIII wieku, Wydawnictwo Uniwersytetu Śląskiego, Katowice 2013.

Mostert Marco, Introduction, w: Medieval Legal Process. Physical, Spoken and Written Performance in the Middle Ages, red. Marco Mostert, Paul S. Barnwell, Brepols, Turnhout 2011 (seria: „Utrecht Studies in Medieval Literacy” t. 22), s. 1-10.

Mrozowski Krzysztof, Spór „o spadek y o ymieye” a kultura prawna mieszkańców Starej Warszawy w połowie XVI wieku, KHKM 61, 2013, 2, s. 292-294.

Poeck Dietrich W., Rituale der Ratswahl. Zeichen und Zeremoniell der Ratssetzung in Europa (12.-18. Jahrhundert), Böhlau, Köln 2003 (seria: „Städteforschung. Veröffentlichungen des Instituts für vergleichende Städtegeschichte in Münster" t. 66). 
Resztak Miłosz, Ze studiów nad kultura prawna kancelarii miejskiej późnośredniowiecznego Lublina, w: Coram iudicio. Studia z dziejów kultury prawnej w miastach późnośredniowiecznej Polski, red. Agnieszka Bartoszewicz, IH UW, DiG, Warszawa 2013, s. 109-125.

Samsonowicz Henryk, Kultura prawnicza miast polskich $w$ średniowieczu, w: Mente et litteris. o kulturze i społeczeństwie wieków średnich, red. Helena Chłopocka et al., Wydaw. Naukowe UAM, Poznań 1984, s. 319-325.

Schmidt-Wiegand Ruth, Gebärdensprache im mittelalterlichen Recht, „Frühmittelalterliche Studien" 16, 1982, s. 363-379.

Schmidt-Wiegand Ruth, Recht und Gesetz im Spannungsfeld zwischen Schriftlichkeit und Mündlichkeit im Mittelalter, „Frühmittelalterliche Studien” 27, 1993, s. 147-166.

Schmitt Jean-Claude, Gest w średniowiecznej Europie, Oficyna Naukowa, Warszawa 2006.

Szende Katalin, Testamenty i ustne oświadczenia woli. Oralność i piśmienność w procesie sporzadzania testamentów na Wegrzech w późnym średniowieczu, KHKM 61, 2013, 2, s. 223-238.

Wysmułek Jakub, Testamenty mieszczan krakowskich (XIV-XV wiek), PTH, Neriton, Warszawa 2015.

Wyżga Mateusz, Ceremonie na ratuszu krakowskim w XV-XVIII wieku, RDSG 74, 2014, s. $139-159$.

Zupka Dušan, Ritual and Symbolic Communication in Medieval Hungary under the Árpád Dynasty (1000-1301), Brill, Leiden-Boston 2016 (seria: „East Central and Eastern Europe in the Middle Ages, 450-1450" t. 39).

Biogram: Agnieszka Bartoszewicz - prof. dr hab., Instytut Historyczny Uniwersytetu Warszawskiego, profesor UW; zainteresowania: kultura pisma w Europie XIII-XV w.; kontakt: abartoszewicz@uw.edu.pl. 